\title{
TESTOVANIE LINEÁRNEJ ZÁVISLOSTI RIZIKA A MIERY VÝNOSNOSTI V ROVNOVÁŽNOM MODELY CAPM
}

\author{
Jozef Glova
}

Kl'účové slova:

Oceňovanie aktív, modely oceňovania kapitálových aktív, testovanie hypotéz.

\section{Key words:}

Asset pricing, capital asset pricing models, hypothesis testing.

\begin{abstract}
Abstrakt
Článok sa zaoberá rovnovážnym modelom CAPM s ciel'om formulovat' a testovat' hypotézu, ktorú by takýto rovnovážny model mal potvrdzovat' $s$ ohl'adom na jeho použitel'nost'. Preskúmali sme hypotézu, či stratégie rozdelenia aktív s ohl'adom na relatívnu mieru rizika (Beta) za dlhšie časové obdobie sú v súlade s modernou teóriou portfólia, a teda aj modelom CAPM. Vzhl'adom $\mathrm{k}$ tomu sme formulovali hypotézu, že vyššie riziko, vyjadrené prostredníctvom Beta koeficientu, je asociované s vyššou mierou výnosnosti, a že táto výnosnost' je významne lineárne závislá na nezávislej premennej. Pre testovanie hypotézy sme na empirických údajoch aplikovali dvojicu testov modelu CAPM, a to Sharpeho a Cooperov test a test od Blacka, Jensena a Scholesa.
\end{abstract}

\begin{abstract}
This article explores CAPM equilibrium model with the objective to formulate and test hypotheses that should equilibrium model of capital asset pricing holds whether one believes in this model. We examined whether the strategies with respect to risk (Beta) over long period produce returns consistent with modern capital theory, as well as of CAPM model. Therefore we formulated an hypotheses whether higher risk, expressed by Beta, should be associated with a higher level of return and whether the return is linearly related to market portfolio through Beta coefficient significantly. To test this hypothesis on empirical data we used two tests of CAPM model, test of Sharpe and Cooper and test of Black, Jensen, and Scholes.
\end{abstract}

\section{Úvod}

Model CAPM, zvyčajne označovaný ako model oceňovania kapitálových aktív, je fundamentálnym základom na vyjadrenie spôsobu vyjadrenie ceny finančných nástrojov kapitálového trhu. Pri existencií všetkých predpokladov modelu CAPM (bližšie vid'. [7] alebo tiež [10]), jediné portfólio rizikových aktív, ktoré investor bude chciet' vlastnit' je trhové portfólio, tiež nazývané aj ako takzvané tangenciálne portfólio.

Rozhodujúcimi parametrami, na základe ktorých sa investori rozhodujú pri investovaní, a to či už do jednotlivých akcií alebo ich kombinácií, teda portfólií je očakávaný výnos, ktorý im investícia prinesie, a riziko, ktoré budú musiet' podstúpit'. Model CAPM slúži investorom práve na vyjadrenie vzt’ahu medzi rizikom a výnosom, avšak tu sa zároveň otvára priestor pre testovanie funkcionality tohto modelu s prihliadnutím na rôzne obmedzenia a jeho modifikácie.

Tento príspevok je rozdelený do dvoch hlavných častí. Prvá v stručnej forme objasňuje princíp fungovania modelu CAPM a jeho predpoklady. Druhá, analytická čast' je zameraná na testovanie modelu CAPM pomocou testu Sharpeho a Coopera ako aj testu od Blacka, Jensena 
a Scholesa. Vzhl'adom na to, že hlavnou podstatou týchto testov je zist'ovanie významnosti vzt’ahu medzi rizikom portfólia a jeho výnosom počas celého sledovaného obdobia, budeme sa aj my snažit' na zvolenej vzorke 100 akcií o potvrdit', resp. zamietnut' hypotézu o existencií významnej lineárnej závislosti.

\section{Model oceňovania kapitálových aktív - CAPM}

V oblasti kapitálových aktív majú výrazný vplyv pre definovanie požadovanej miery výnosnosti rovnovážne modely, nazývané tiež ako jednofaktorové alebo viacfaktorové modely, ktoré prostredníctvom vysvetl'ujúcich premenných (faktora alebo indexu) determinujú vysvetl'ovanú premennú, prevažne požadovanú mieru výnosnosti alebo nadmernej výnosnosti kapitálového aktíva alebo skupiny takýchto aktív (portfólií).

Model CAPM vysvetl'uje proces tvorby cien rizikových aktív na kapitálovom trhu. Objasňuje vzt’ah medzi očakávaným výnosom aktíva a jeho rizikom za podmienok rovnováhy na trhu, kde všetci investori volia optimálne portfólio. Očakávané výnosy cenných papierov alebo portfólia sa rovnajú miere výnosu z bezrizikového aktíva plus rizikovej prémii. Ked' sa tento očakávaný výnos nevyrovná alebo neprevýši požadovaný výnos, investícia by nemala byt' uskutočnená. Táto štandardná forma vzt’ahu všeobecnej rovnováhy pre výnosy aktív bola v 60. rokoch nezávislé na sebe navrhnutá a odvodená autormi Sharpe, Lintner a Mossin. Tento model, tiež nazývaný ako Sharpe-Lintner-Mossinov model, nadväzuje na teoretické práce Harryho Markowitza [4][5] a Jamesa Tobina [12] v oblasti diverzifikácie a modernej teórie portfólia, pričom bol nezávisle predstavený Jackom Treynorom [13], Williamom Sharpem [7], Johnom Lintnerom [3] a Janom Mossinom [6]. Model berie do úvahy citlivost' kapitálového aktíva na nediverzifikovatel'nú zložku rizika (systematické riziko), reprezentované relatívnou mierou rizika $\mathrm{v}$ podobe beta (ß) koeficientu, ako aj očakávanú výnosnost' trhu a očakávanú výnosnost' teoreticky definovaného bezrizikového aktíva, a to na základe definovaných predpokladov. Model CAPM sa zvyčajne vyjadruje v podobe procesu generujúceho výnosnost' alebo charakteristickej priamky cenného papiera, pričom je vhodne modifikovatel'ný na všeobecný jednofaktorový model.

V prípade tohto modelu boli predpoklady pre definovanie efektívnej množiny podl'a Markowitza a Tobina doplnené a spolu tak tvoria základ pre model CAPM. Medzi jednotlivými predpokladmi sú uvedené tieto: Neexistujú transakčné náklady. Jednotlivé aktíva sú nekonečne delitel'né. Neexistencia daní z príjmu. Jednotlivec nemôže ovplyvnit' cenu akcie svojim nákupným alebo predajným rozhodnutím. Od investorov sa očakáva uskutočnit' rozhodnutia samostatne z hl'adiska očakávaných výnosnosti a štandardných smerodajných odchýlok ich portfólií. Prípustnost' neobmedzeného predaja na krátko. Neobmedzené požičiavanie a vypožičanie si za bezrizikovú úrokovú sadzbu. Homogenita očakávania investorov ohl'adom výnosnosti a ich variability. Informácie sú vol'né a okamžite dostupné všetkým investorom. Všetky aktíva sú predajné (speňažitel'né). Podrobnejšie pre bližší popis predpokladov odporúčam použit' zdroj [10]

Ako je z prehl'adu týchto predpokladov zrejmé, CAPM redukuje situáciu na hraničný prípad. To dovolí presunút' pozornost' na to, čo sa stane s cennými papiermi, ked' budú mat' všetci investori rovnaké podmienky a všetci budú investovat' podobným spôsobom. A na základe sledovania kolektívneho správania sa investorov môže byt' odvodená podstata výsledného vzt'ahu medzi rizikom a výnosnost’ou každého cenného papiera.[8] 


\section{Testovanie rovnovážnych modelov stanovenia cien kapitálových aktív}

Ekonomické modely sa vo všeobecnosti snažia vystihnút' komplexnost' ekonomickej reality, s čím je samozrejme spojená nevyhnutnost' určitých prispôsobení alebo zjednodušení. So zavedením takýchto zjednodušení však súvisí možná nepresnost' ekonomického modelu voči ekonomickej realite. Z tohto dôvodu je nevyhnutné poznat' takúto nepresnost', čo je možné vykonat' použitím vhodne zvolených typov testov.

Testovanie ekonomických modelov, a v tomto prípade jednoduchého modelu CAPM nám umožňuje poznat' nakol'ko správne jednoduchý model CAPM popisuje správanie sa súčasných kapitálových trhov.

Mnoho testov zo všeobecných modelov rovnováhy sa zaoberá či už štandardným CAPM, alebo nulovou formou beta (Zero-beta) všeobecného rovnovážneho modelu. Základný model CAPM je možné vo všeobecnosti zapísat' ako

kde:

$$
E\left(R_{i}\right)=R_{f}+\beta_{i} \cdot\left[E\left(R_{m}\right)-R_{f}\right]
$$

$R_{f}$ - bezriziková sadzba,

$\beta_{i}$ - beta faktor, ktorý vyjadruje citlivost' investície $i$ na zmenu výnosovej miery trhového portfólia,

$E\left(R_{m}\right)$ - očakávaná výnosová miera trhového portfólia,

$E\left(R_{i}\right)$ - očakávaná výnosnost' miera aktíva $i$.

Bez uvažovaných možnosti požičania alebo zapožičania dodatočných peňažných fondov je možné uvažovat' aj tzv. dvojfaktorový (Zero-beta) model, ktorý je definovaný ako

$$
E\left(R_{i}\right)=E\left(R_{Z}\right)+\beta_{i} \cdot\left[E\left(R_{m}\right)-E\left(R_{Z}\right)\right]
$$

kde:

$\mathrm{E}\left(\mathrm{R}_{\mathrm{i}}\right)$ - očakávaná výnosová miera aktíva i,

$\mathrm{E}\left(\mathrm{R}_{\mathrm{z}}\right)$ - očakávaná výnosová miera portfólia s nulovým beta faktorom, ktorá má najnižšiu smerodajnú odchýlku,

$\beta_{\mathrm{i}}$ - beta faktor, ktorý vyjadruje citlivost' investície i na zmenu výnosovej miery trhového portfólia,

$\mathrm{E}\left(\mathrm{R}_{\mathrm{m}}\right)$ - očakávaná výnosová miera trhového portfólia,

Tieto modely sú formulované v zmysle očakávaní a všetky premenné sú vyjadrované v zmysle budúcich hodnôt. Relevantné beta je budúce beta cenných papierov. Okrem toho, aj výnos trhu, aj výnos portfólia pri minimálnej odchýlke nulového beta sú očakávanými budúcimi výnosmi.

Vzhl'adom na absenciu dostupných systematických dát týkajúcich sa očakávaní investorov, takmer všetky testy rovnovážnych modelov (teda aj modelu CAPM) sú realizované s použitím pozorovaných hodnôt premenných (ex-post hodnotami).

Tu sa otvára logická otázka, ako nastavit’ testovanie rovnovážneho modelu. Na základe expost analýzy súhrnných a parciálnych výsledkov je možné získat' informácie pre ex-ante analýzy, a teda zistit' očakávané budúce výnosy investorov. [1] 
Obhajoba takéto postupu stojí na dvoch úvahách. Tá jednoduchšia obhajoba znamená dokazovat', že očakávania sú v priemere, ale aj ako celok správne. Preto počas vel'mi dlhého časového obdobia sa aktuálne udalosti môžu považovat' za očakávania. Komplexnejšia obhajoba sa začína predpokladom, že výnosy cenných papierov lineárne súvisia s výnosom v trhovom portfóliu. Tento model, nazývaný trhovým modelom, je daný ako:

kde

$$
\tilde{R}_{i t}=\alpha_{i}+\beta_{i} \cdot \tilde{R}_{m t}+\tilde{e}_{i t}
$$

$\tilde{R}_{i t}-$ výnosnost' kapitálového aktíva (napr. akcie),

$\alpha_{i}$ - predstavuje očakávanú hodnotu časti výnosnosti cenného papiera $i$, ktorá je nezávislá od výkonnosti trhu,

$\beta_{i}$ - konštanta určujúca očakávanú zmenu v $\widetilde{R}_{i t}$, danú zmenou v $\widetilde{R}_{m t}$,

$\tilde{R}_{m t}$ - predstavuje mieru výnosnosti trhového indexu, pričom opätovne ide o náhodnú premennú,

$\tilde{e}_{i t}$ - náhodná čast’ výnosnosti cenného papiera $i$, ktorá je nezávislá od výkonnosti trhu.

Očakávaná hodnota výnosu cenného papiera $i$ je:

$E\left(R_{i}\right)=\alpha_{i}+\beta_{i} \cdot E\left(R_{m}\right)$

teda

$E\left(R_{i}\right)-\alpha_{i}-\beta_{i} \cdot E\left(R_{m}\right)=0$

Pridaním tejto rovnice na pravú stranu rovnice (3) a jej upravením získame:

$\tilde{R}_{i t}=E\left(R_{i}\right)+\beta_{i} \cdot\left[\tilde{R}_{m t}-E\left(R_{m}\right)\right]+\tilde{e}_{i t}$

Jednoduchá forma modelu CAPM je:

$E\left(R_{i}\right)=R_{F}+\beta_{i} \cdot\left[E\left(R_{m}\right)-R_{f}\right]$

Substitúciou výrazu E(Ri) v predchádzajúcej rovnici a jej zjednodušením dostaneme:

$\tilde{R}_{i t}=R_{f}+\beta_{i} \cdot\left(R_{m t}-R_{f}\right)+\tilde{e}_{i t}$

Testovanie modelu tejto formy s ex-post dátami sa zdá byt' vhodné. Avšak, existujú tri predpoklady súvisiace s týmto modelom:

- Trhový model platí počas celej doby.

- Model CAPM platí počas celej doby.

- Beta je stabilné $v$ čase $t$, kde $t=1,2,3, \ldots \ldots . . . N$.

Test tohto modelu s použitím ex-post dát je skutočne simultánny test všetkých týchto troch hypotéz. Ak by sme použili dvojfaktorový model namiesto Sharpe-Lintner-Mossinovej formy, dospeli by sme k rovnici:

$\tilde{R}_{i t}=\tilde{R}_{Z t}+\beta_{i} \cdot\left(\tilde{R}_{m t}-\tilde{R}_{Z t}\right)+\tilde{e}_{i t}$

a nie k rovnici (8). 


\section{Testovanie modelu CAPM}

\section{Vzorka dát}

Testovanie realizujeme na údajoch 100 náhodne vybraných akcií z indexu S\&P 500, obchodovaných na NYSE, AMEX a NASDAQ v období januára 1999 až decembra 2009 (11 rokov). Pre analýzu použijeme priemer denných uzatváracích cien za dané obdobie. Z pohl'adu vybranej formy testu výplatu dividend budeme, resp. nebudeme uvažovat'. Rovnako budeme postupovat' aj pri spracovaním údajov za trhové portfólio, ktoré bude zastúpené indexom S\&P 500. Ako hodnoty bezrizikových sadzieb sú vybrané údaje o výnosnosti cenných papierov štátnej pokladne vlády USA s 1 mesačnou splatnost'ou. Hodnoty všetkých výnosnosti sú prepočítané na mesačnú bázu (per month - p.m.).

\section{Hypotézy}

$\boldsymbol{H}_{0}$ : Existuje lineárna závislost' medzi rizikom vyjadreným koeficientom beta a výnosom portfólií cenných papierov;

$\mathrm{H}_{1}$ : Hypotézu zamietame.

Pre overenie stanovenej nultej a alternatívnej hypotézy použijeme dvojicu testov. Prvý od Sharpeho a Coopera a druhý od Blacka, Jensena a Scholesa.

\section{Test Sharpeho a Coopera}

Sharpeho a Cooperov test [9] overuje v hypotéze uvedenú lineárnu závislost' medzi rizikom (vyjadreným koeficientom beta) a výnosom pre jednotlivé portfólia cenných papierov. Z nášho pohl'adu budeme sledovat' ako sa tento vzt'ah mení v závislosti so zmenou štruktúry jednotlivých portfólií $\mathrm{v}$ subperiódach $\mathrm{v}$ dôsledku zmien hodnôt beta pre jednotlivé akcie v každej subperióde. Vychádzat’ budeme z rovnice (3):

$\tilde{R}_{i t}=\alpha_{i}+\beta_{i} \cdot \tilde{R}_{m t}+\tilde{e}_{i t}$,

kde $\widetilde{R}_{i t}$ je priemerný výnos portfólia; $\widetilde{R}_{m t}$ je priemerný výnos trhu za danú subperiódu, $\alpha_{i}$ je intercept portfólia, $\beta_{i}$ je riziko portfólia a $\tilde{e}_{i t}$ je chyba modelu.

Pre potreby tohto typu testu vypočítame priemerné mesačné výnosnosti z cien akcií aj indexu S\&P 500. Dalej z týchto hodnôt výnosnosti definujeme nadmerné mesačné výnosnosti daných akcií za vybrané obdobie (Ri-Rf), rovnako ako aj nadmerné mesačné výnosnosti indexu za dané obdobie (Rm-Rf). Parameter (Ri-Rf) predstavuje rozdiel medzi očakávanými mesačnými výnosmi jednotlivých akcií a mesačnými úrokovými sadzbami vyššie zmienenej bezrizikovej investície. Parameter (Rm-Rf) je rozdiel medzi očakávanými mesačnými výnosmi indexu S\&P a mesačnými úrokovými sadzbami bezrizikovej investície za dané obdobie.

Pre d’alšie výpočty sme definovali subperiódy, kedy každá subperióda predstavuje obdobie zložené z piatich rokov (spolu 60 mesiacov). Interval prvej subperiódy možno zapísat' aj nasledovne: $(t ; t+5), k d e t=1,2, \ldots . .11$, t.j. počet rokov pozorovania. Každá d'alšia subperióda je posunutá o jeden rok $(\mathrm{t}+1 ; \mathrm{t}+6)$. Celková vzorka bola rozdelená na 7 subperiód, teda 1 . subperióda je v rozpätí rokov 1999 až 2003, 2. subperióda od 2000 do 2004, atd'.

Nadmerná výnosnost' (Ri-Rf), inak nazývaná aj riziková prémia pre i-té aktívum, a nadmerná výnosnost' (Rm-Rf), nazývaná tiež celková trhová riziková prémia, boli použité pre výpočet parametrov beta (slope), alfa (intercept), priemerný výnos (average return), riskless rate (bezriziková úroková miera) a priemerná hodnota výnosnosti trhu (E(Rmt)) pre každé portfólio všetkých subperiód. 
Pre každú zo siedmych subperiód platí, že vzorka 100 akcií je zotriedená podl'a výšky hodnôt beta od najväčšej po najmenšiu. Celková vzorka teda tvorí 10 portfólií, kde každé portfólio pozostáva z 10 akcií. V prvom portfóliu sa nachádza 10 akcií, ktoré majú najvyššie hodnoty beta zo všetkých 100 akcií a v poslednom portfóliu zase 10 akcií s najnižšími hodnotami beta zo všetkých akcií. Zloženie portfólia sa každou subperiódou mení z dôvodu rôznych hodnôt beta $\mathrm{v}$ čase.

Pre každé portfólio všetkých subperiód boli vypočítané potrebné hodnoty parametrov, a to také, ako pre jednotlivé akcie subperiód. Teda hodnoty beta, alfa, priemerný výnos, a priemerná úroková sadzba za dané portfólio, ktorých výsledky sú prezentované v d'alších podkapitolách. Naviac sme určili korelačný koeficient, ktorý predstavuje vzájomnú závislost' medzi hodnotami beta a výnosmi jednotlivých portfólií. Týmto spôsobom vzniklo 7 súhrnných tabuliek pre každú subperiódu pozostávajúcich z 10 portfólií za sledované obdobie 11 rokov.

Vzhl'adom však na rozsah príspevku prezentujeme len súhrnný prehl'ad spriemerovaných hodnôt všetkých subperiód. To znamená, že prvé portfólio v súhrnnej tabul'ke je vlastne priemerná hodnota všetkých prvých portfólií zo všetkých siedmych subperiód, atd'.

\section{Súhrnný prehl'ad výsledkov testu Sharpeho a Coopera}

Súhrnná tabul'ka predstavuje spriemerované hodnoty počas všetkých siedmych subperiód. Na základe výsledkov možno zhodnotit', že riziko beta sa v priemere pre všetky portfólia všetkých subperiód rovná hodnote 0,95743 pri priemernej výnosnosti $0,50 \%$ a $0,43 \%$ odchýlke. Priemerný korelačný koeficient pre všetky portfólia všetkých subperiód je 6,31\% a spol'ahlivost' tohto modelu je $\mathrm{R}=0,8769$

Krivka na Obrázok 1 má rastúcu tendenciu, čiže aj vzt’ah medzi rizikom a výnosom je v sumáre silne lineárny. Avšak tvrdenie, že s rastúcim beta rastie aj priemerný výnos neplatil vždy pre všetky subperiódy za sledované obdobie (pozri Tabul'ka 1).

Tabul'ka 1: Súhrnný prehl'ad hodnôt skúmaných parametrov

\begin{tabular}{|l|l|l|l|l|}
\hline & $\begin{array}{l}\text { Risk-free } \\
\text { rate } \\
\text { SLOPE } \\
\text { Summary }\end{array}$ & 0,01783 & $\begin{array}{l}\text { E(Rmt) } \\
\text { Average }\end{array}$ & $\begin{array}{l}0,00742 \\
\text { Correlation } \\
\text { coef. }\end{array}$ \\
\hline \hline 1 & 2,74589 & 0,00805 & 0,0114836 & 0,34585 \\
2 & 1,82956 & 0,00461 & 0,0065989 & $-0,07540$ \\
3 & 1,47238 & 0,00478 & 0,0063631 & $-0,16770$ \\
4 & 1,26648 & 0,00453 & 0,0060114 & 0,10643 \\
5 & 1,06589 & 0,00225 & 0,0035879 & 0,17107 \\
6 & 0,84897 & 0,00201 & 0,0031662 & 0,11654 \\
7 & 0,70334 & 0,00154 & 0,0025163 & 0,21189 \\
8 & 0,57391 & 0,00419 & 0,0050357 & 0,01970 \\
9 & 0,44089 & 0,00436 & 0,0049824 & $-0,02217$ \\
10 & 0,16159 & 0,00277 & 0,0031084 & $-0,00232$ \\
\hline medián & 0,95743 & 0,00428 & 0,0050090 & 0,06307 \\
\hline
\end{tabular}

Prameň: autor, na základe vlastných výpočtov 
Zároveň aj napriek tomu, že dané testovanie bolo uskutočnené na siedmych subperiódach, nemožno jednoznačne potvrdit', že platí vzt'ah medzi beta a interceptom, že ak je hodnota beta väčšia ako 1, tak intercept (teda alfa) bude negatívny.

Treba pripomenút', že daný jednoduchý model pri výnosoch nezohl'adňuje možné dividendy, čiže prémiu pre investora za investované peňažné prostriedky. Preto je možné, že výsledky testu sú skreslené práve o tento predpoklad.

Rovnica modelu CAPM podl'a jednoduchého testu Sharpeho a Coopera za celú sledovanú periódu má tvar:

$\tilde{R}_{i t}=\tilde{R}_{Z t}+\beta_{i} \cdot\left(\tilde{R}_{m t}-\tilde{R}_{Z t}\right)+\tilde{e}_{i t}$

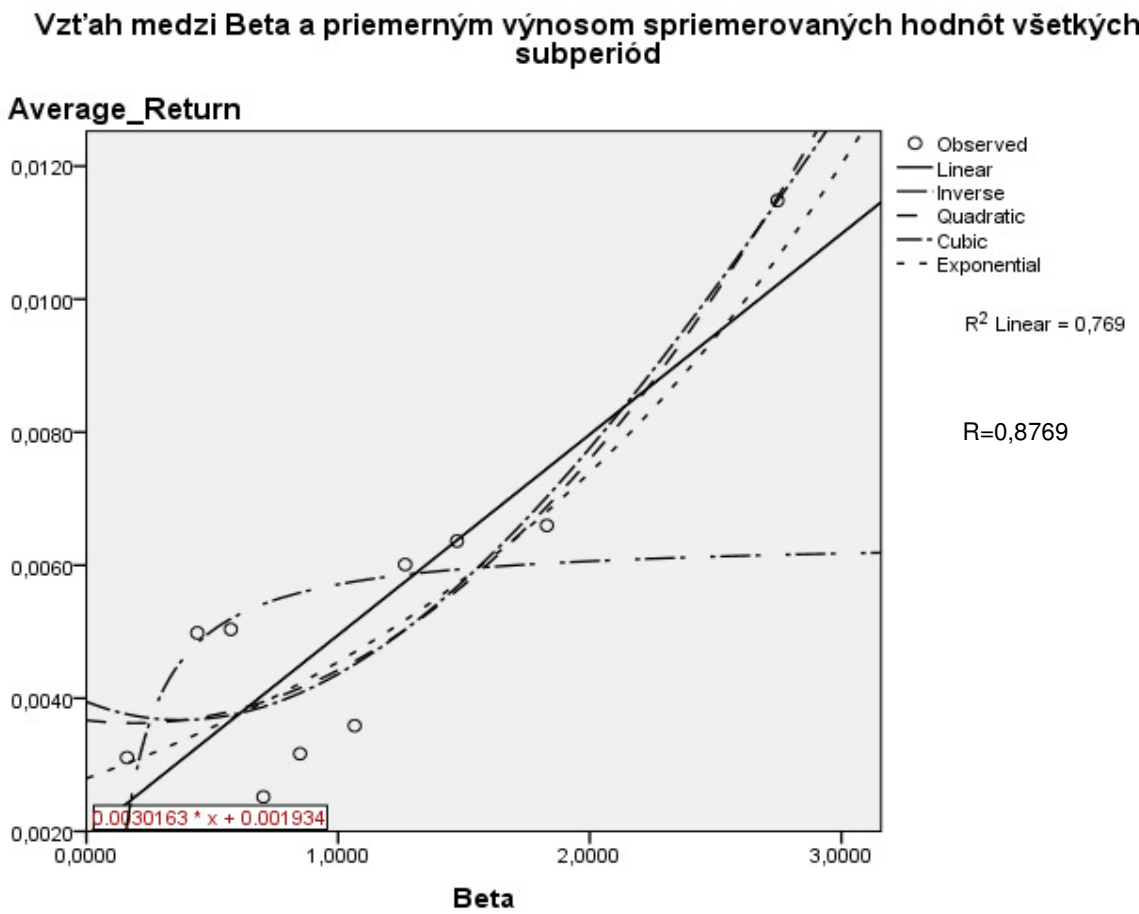

Obrázok 1: Vzt’ah medzi Beta a priemerným výnosom spriemerovaných hodnôt všetkých subperiód

\section{Testovanie modelu CAPM pomocou testu Blacka, Jensena a Scholesa}

Podobne ako Sharpe a Coope (d'alej tiež SC), tak aj Black, Jensen a Scholes (d'alej tiež BJS) testovali, či existuje lineárna závislost' medzi rizikom beta a výnosom [11]. Avšak Sharpe a Cooper pozorovali vzt'ah beta a priemerného výnosu (average return) za dané portfólio (subperiódu), kým BJS pozorovali vzt’ah beta a diferenčného výnosu (excess return) za dané portfólio (subperiódu). Diferenčný výnos portfólia (a teda aj subperiódy) je upravený o bezrizikovú úrokovú mieru, teda od priemerného výnosu portfólia je odpočítaná priemerná mesačná bezriziková úroková miera danej subperiódy.

Testovanie modelu CAPM podl'a testu BJS je založené na podobnom princípe ako test SC. Líši sa vo vstupných údajoch akcií aj indexu S\&P 500, vo výpočtoch výnosu a korelačného koeficientu. Ked’že test BJS na rozdiel od testu SC predpokladá existenciu dividend a jej zahrnutie do modelu, bolo potrebné použit' uzatváracie ceny akcií a indexu S\&P upravené 
o tieto dividendy, čiže AdjClose. Korelačný koeficient $v$ tomto prípade vyjadruje silu vzájomného vzt'ahu medzi nadmernou výnosnost'ou akcií (Ri-Rf) a nadmernou výnosnost'ou trhu (Ri-Rm) danej subperiódy. ${ }^{1}$ Black, Jensen a Scholes taktiež skúmajú lineárnu závislost' medzi korelačným koeficientom a rizikom.

Postup zist'ovania a výpočtov koeficientov beta a intercept je zhodný, ako pri predchádzajúcom teste. Aj tu každá subperióda prislúcha určitému obdobiu a ich rozdelenie na 7 subperiód je rovnaké ako pri teste SC. Budeme vychádzat' z tejto rovnice:

$$
R_{i t}-R_{f t}=\alpha_{i}+\beta_{i} \cdot\left(R_{m t}-R_{f t}\right)+e_{i t}
$$

\section{Súhrnný prehl’ad výsledkov testu Blacka, Jensena a Scholesa}

Súhrnný prehl'ad rovnako ako pri teste $\mathrm{SC}$, tak aj v tomto prípade predstavuje spriemerované hodnoty počas všetkých siedmych subperiód za celé sledované obdobie (11 rokov). Ako je opätovne z Tabul'ka 2 vidiet', odhadné hodnoty beta sa pohybovali od 0,18366 do 2,64733, čo $\mathrm{v}$ je priemere 0,95938 .

Tabul'ka 2: Súhrnný prehl'ad hodnôt skúmaných parametrov

\begin{tabular}{|l|l|l|l|l|}
\hline Summary & $\begin{array}{l}\text { SLOPE } \\
\text { (Beta) }\end{array}$ & Intercept & $\begin{array}{l}\text { Excess } \\
\text { return }\end{array}$ & $\begin{array}{l}\text { Correlation } \\
\text { coef. }\end{array}$ \\
\hline \hline 1 & 2,64733 & 0,01071 & 0,0045543 & 0,60326 \\
2 & 1,86460 & 0,01208 & 0,0067473 & 0,57832 \\
3 & 1,49118 & 0,01274 & 0,0080156 & 0,54757 \\
4 & 1,26982 & 0,00876 & 0,0044298 & 0,56933 \\
5 & 1,06493 & 0,00708 & 0,0031038 & 0,51230 \\
6 & 0,85382 & 0,00610 & 0,0024854 & 0,44579 \\
7 & 0,69645 & 0,00496 & 0,0015990 & 0,40081 \\
8 & 0,56553 & 0,00711 & 0,0039700 & 0,36677 \\
9 & 0,44547 & 0,00751 & 0,0044900 & 0,31237 \\
\hline 10 & 0,18366 & 0,00754 & 0,0049157 & 0,13645 \\
\hline medián & 0,95938 & 0,00752 & 0,0044599 & 0,47904 \\
\hline
\end{tabular}

Prameň: autor, na základe vlastných výpočtov

Diferenčný výnos sa síce nepohyboval priamo úmerne počas celej subperiódy, ale z Obrázok 2 je pomocou rastúcej trendovej krivky zrejmé, že vzt'ah medzi výnosom a rizikom je koniec koncom lineárny. Daná krivka má rovnicu s kladnou smernicou rovnú: y=0,00097.x+0,00335. Priemerná hodnota interceptu (teda odchýlky modelu) je cca 0,0075 a priemerná korelácia medzi nadmernou výnosnost'ou trhu a nadmernou výnosnost'ou portfólia je 0,479. Tento lineárny model má však hodnotu determinácie len 0,144.

Rovnica modelu CAPM podl’a testu Blacka, Jensena a Scholesa za celú sledovanú periódu má tvar:

$E\left(R_{i}\right)=0,00752-0,00240 . \beta_{i}$

\footnotetext{
1 Pri teste SC je to korelácia medzi samotným koeficientom beta a priemerným výnosom.
} 


\section{Vzt'ah medzi Beta a diferenčným výnosom spriemerovaných hodnôt všetkých subperiód}

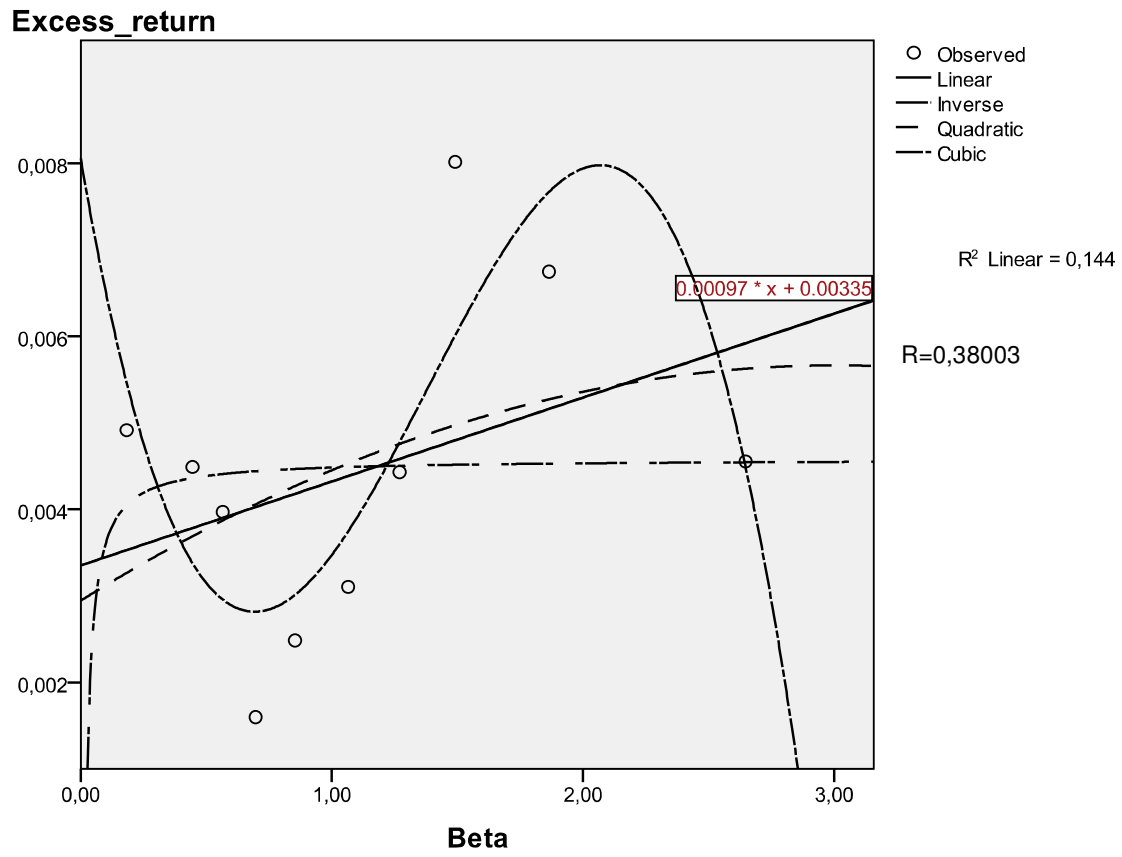

Obrázok 2: Vzt’ah medzi Beta a diferenčným výnosom spriemerovaných hodnôt všetkých subperiód

\section{Porovnanie výsledkov oboch testov}

Najprv by bolo vhodné pripomenút' hlavné rozdiely medzi testom Sharpeho a Coopera a testom Blacka, Jensena a Scholesa, ktoré podl'a všetkého sú hlavnými dôvodmi odlišností, či už vo vývoji trendových kriviek alebo jednotlivých výnosnosti, rizík a odchýlok v portfóliách v rámci subperiód. Konkrétne ide o rozdiely vo vstupných dátach (len uzatváracie ceny akcií $\mathrm{a}$ indexu pre výpočty $\mathrm{v}$ teste SC; uzatváracie ceny upravené o dividendy $\mathrm{v}$ teste BJS), vo výpočtoch výnosnosti (len priemerná pre test SC; diferenčná pre test BJS) a určovanie vzájomnej závislosti dvoch premenných (vzt'ah medzi rizikom beta a priemerným výnosom pre test SC; vzt'ah medzi nadmernou výnosnost'ou trhu a nadmernou výnosnost'ou portfólia pre test BJS).

Z porovnania vypočítaných hodnôt $\mathrm{v}$ rovnakých subperiódach zistíme, že rozdiely v hodnotách nie sú významne vel'ké, líšia sa ale hlavne vodchýlkach modelu od rovnovážneho a v spol'ahlivosti daných modelov.

Vzt'ah rizika beta a výnosu je v sumáre podl'a oboch testov lineárny, aj ked' sa v jednotlivých subperiódach výrazne menil. Trendová krivka v teste SC je klesajúca len počas druhej a šiestej subperiódy, zatial' čo v teste BJS je okrem iného klesajúca aj počas štvrtej a siedmej subperiódy. Zjavne aj to je príčinou strmšej lineárnej krivky súhrnného modelu, a teda aj silnejšieho vzt’ahu medzi rizikom a výnosom, v teste SC.

Najvýznamnejšia lineárna závislost' (podl'a koeficientu determinácie lineárneho regresného modelu) medzi rizikom a výnosom je počas prvej subperiódy, kde trendová krivka je najšikmejšia, a to aj podl'a testu Sharpeho a Coopera, aj podl'a testu Blacka, Jensena a Scholesa. 
To, aké vstupné údaje budú použité, aké parametre budú skúmané a čo sa týmto sleduje, závisí od rozhodnutia samotného investora. Ten aj vd'aka týmto testom môže sledovat' rozdielnosti vo výsledkoch pri nezahrnutí určitých predpokladov do testovania.

\section{Záver}

Hlavným prínosom tohto príspevku bolo poukázat' na spôsoby a postupy overovania lineárneho závislosti medzi rizikom a výnosom v rovnovážnom modely pre stanovenie cien kapitálových aktív CAPM, a to tak na základe testu Sharpeho a Coopera ako aj na základe testu od Blacka, Jensena a Scholesa.

Model sme testovali na skúmanej vzorke 100 náhodne vybraných akcií obsiahnutých v indexe S\&P 500 za obdobie 11 rokov a na základe výsledkov možno v sumáre potvrdit' existenciu lineárneho vzt'ahu, a teda tak potvrdit' stanovenú testovaciu hypotézu. Táto lineárna väzba medzi rizikom (Beta) a výnosom však neplatila počas všetkých subperiód za sledované obdobie, jej vyššia spol'ahlivost' však bola tiež výraznejšie potvrdená v prípade prvého z dvojice aplikovaných testov.

\section{Príspevok vznikol ako čiastočný výsledok riešenia projektu VEGA č. 1/0897/10.}

\section{Literatúra:}

[1] ELTON E.J., GRUBER M. J. Modern Portfolio Theory and Investment Analysis. 7. vyd. New York: Wiley, 2006, 330-339 s. ISBN 04-79950-82-9

[2] LINTNER, J. The Market Price of Risk, Size of Market and Investor's Risk Aversion. In. Review of Economics and Statistics, ročník 52, č. 1, 1970, 87-99 s. ISSN 0034-6535

[3] LINTNER, J. The valuation of risk assets and the selection of risky investments in stock portfolios and capital budgets. In: Review of Economics and Statistics, ročník 47, č. 1, 1965, 13-37 s. ISSN 0034-6535

[4] MARKOWITZ, H. M. Portfolio Selection. In: The Journal of Finance, ročník 7, č. 1, 1952, 77-91 s. ISSN 0022-1082

[5] MARKOWITZ, H. M. Portfolio Selection: Efficient Diversification of Investments. 1. vyd. New York: John Wiley \& Sons., 1959. Dostupné na http://cowles.econ.yale.edu/P/cm/m16/m16-all.pdf.

[6] MOSSIN, J. Equilibrium in a Capital Asset Market. In: Econometrica, ročník 34, č. 4, 1966, 768-783 s. ISSN 0012-9682

[7] SHARPE, W. F. Capital Asset Prices: A Theory of Market Equilibrium under Conditions of Risk. In: Journal of Finance, ročník 19, č. 3, 1964, 425-442 s. ISSN 0022-1082

[8] SHARPE, W. F. Risk Market Sensitivity and Diversification. In: Financial Analysts Journal, ročník 28, č. 1, 1972, 74-79 s. ISSN: 0015-1984

[9] SHARPE, W.F.; COOPER G.M. „Risk-Return Class of New York Stock Exchange Common Stocks, 1931-1967. In: Financial Analysts Journal, ročník 28, č. 2, 1972, 46-52 s. ISSN: 0015-1984

[10] SHARPE, W. F.; GORDON, A. J. Investice. 1. vyd. Praha: Victoria Publishing, 1994, 1162 s. ISBN 80-85605-47-3

[11] SCHOLES, M., BLACK, F. JENSEN, M. C.: Capital Asset Pricing Model: Some Empirical Tests. In: Studies in the Theory of Capital Markets, Praeger Publishers Inc., 1972.

[12] TOBIN, J. Liquidity Preference as Behavior Towards Risk. In: Review of Economic Studies, ročník 25, č. 1, 1958, 65-86 s. ISSN 0034-6527 
[13] TREYNOR, J. Toward a Theory of Market Value of Risky Assets. In: Asset Pricing and Portfolio Performance: Models, Strategy and Performance Metrics. London: Risk Books, 1999, 15-22 s. ISBN 1899332367

\section{Klasifikace JEL: C12, C58, G12}

\section{Ing. Jozef Glova, PhD.}

Odborný asistent Katedra bankovníctva a investovania

Ekonomická fakulta

Technická univerzita

Němcovej 32, 04200 Košice

Slovenská republika

jozef.glova@tuke.sk 